ИЗВЕСТИЯ АКАДЕМИИ НАУК ЭСТОНСКОИ ССР. ТОМ 26 ХИМИЯ * ГЕОЛОГИЯ. 1977, № 3

\title{
ВЛИЯНИЕ СТРУКТУРЫ БЕНЗОПРОИЗВОДНЫХ АНТРАЦЕНА НА КИНЕТИКУ ФОТОИНИЦИИРОВАННОГО ОКИСЛЕНИЯ БЕНЗ(а) ПИРЕНА
}

Lia PAALME, M. GUBERGRITS. ANTRATSEENI BENSODERIVAATIDE MOJU BENSO(a)PUREENI FOTOINITSIEERITUD OKSODEERUMISELE

Lia PAALME, M. GUBERGRITS. INFLUENCE OF STRUCTURE OF BENZOANTHRACENES ON PHOTOINDUCED OXIDATION OF BENZO(a)PYRENE

Йсследования $\left[{ }^{1-3}\right]$ показывают, что скорость фотоинициированного окисления бенз(а)пирена (I) в присутствии других полициклических ароматических углеводородов (ПАУ) определяется структурой и относительной концентрацией последних. При этом одни ПАУ ингибируют, а другие - способствуют ускорению фотопревращения I.

Настоящая работа посвящена изучению влияния структуры и относительной концентрации некоторых бензопроизводных антрацена, сопровождающих I в технических загрязнениях среды, на кинетику совместного с ними фотоокисления I. В качестве соокисляемых компонентов испытаны: бенз (a) антрацен (II), бенз (b) антрацен (III) и дибенз (a, c) -

Таблица 1

Использованные реагенты<smiles>c1ccc2c(c1)cc1ccc3cccc4ccc2c1c34</smiles><smiles></smiles>

III<smiles>c1ccc2cc3cc4ccccc4cc3cc2c1</smiles><smiles>c1ccc2c(c1)c1ccccc1c1cc3c(cc21)CCCC3</smiles>

бенз (а) пирен

бенз (а) антрацен (тетрафен)

бенз (b) антрацен (тетрацен)

дибенз (а, с) антрацен (Gee Lawson Chemicals)
(Fluka AG, Buchs SG)

(British Drug Houses Ltd)

(Schuchardt) 
антрацен (IV). Структура их приведена в табл. 1. Кинетическая характеристика раздельного фотоинициированного окисления бензопроизводных антрацена дана в [ $\left.{ }^{4}\right]$.

В эксперименте использованы установка и методика, описанные нами ранее в [5]. Контроль за изменением содержания I в системе осуществлен с помощью спектрофотометра по максимуму поглощения в области 388 нм с учетом поправки на наличие фона после предварительного хроматографического разделения реакционной смеси в тонком слое окиси алюминия в восходящем потоке с применением в качестве элюента смеси хлороформ — петролейный эфир (1:9) и выделением

Табицца 2

Кинетические показатели соокисления БП и бензопроизводных антрацена

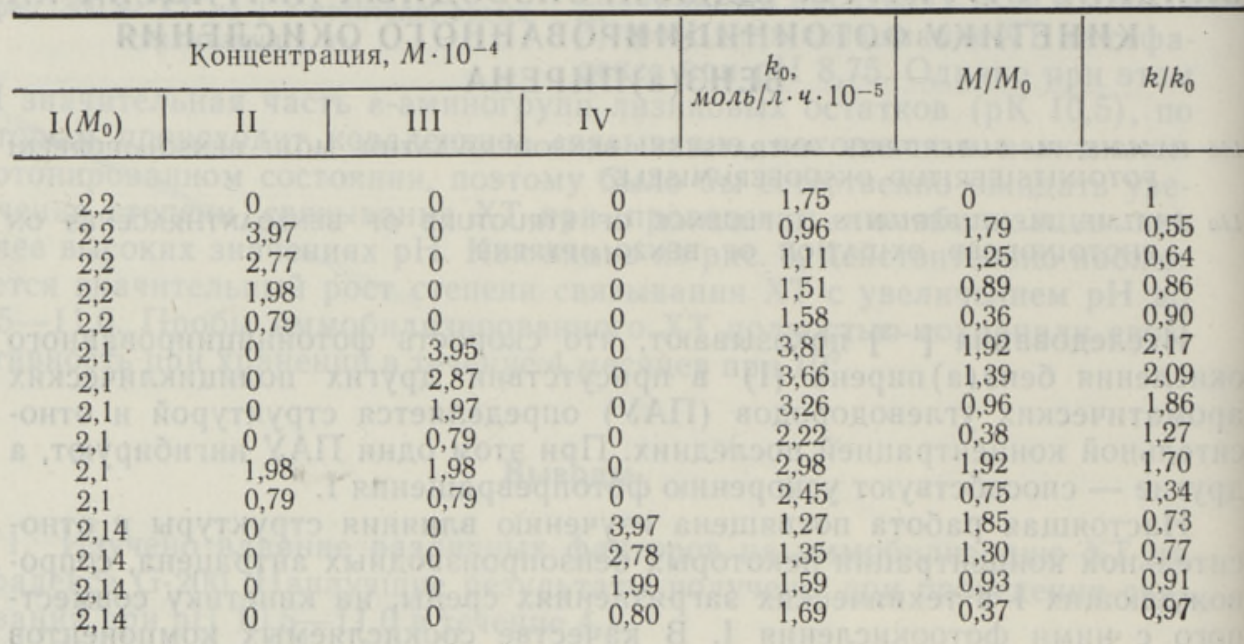

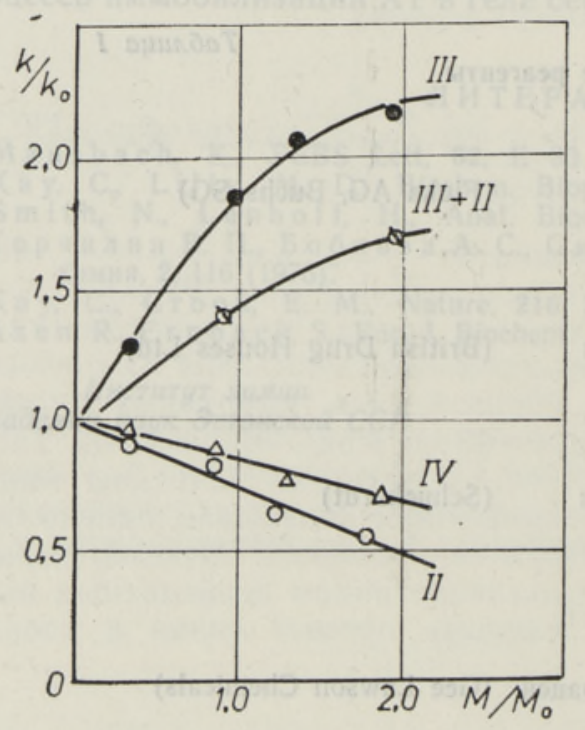

Влияние бензантраценов на фотодеградацию бенз(а)пирена (обозначения см. в табл. 1). зоны скопления I-IV по флуоресценции при облучении в области $360 \mathrm{HM}$.

Испытаны растворы в бензоле «хч» при одинаковой во всех сериях концентрации I $\left(2 \cdot 10^{-4}\right.$ моль/ $\left.\Omega\right)$ и варьировании относительной концентрации компонентов II-IV в пределах, указанных в таб́л. 2.

Установлено, что снижение во времени содержания I в растворе происходит по линейному закону независимо от величины относительной концентрации второго компонента. Это служит свидетельством псевдонулевого порядка суммарной реакции его деградации. На этом основании в работе определены значения констант скорости фотоокисления I для раздельного $\left(k_{0}\right)$ и совместного $(k)$ с одним из компонентов II-IV превращения (см. табл. 2). Кинетические кривые на рисун- 
ке свидетельствуют о закономерном влиянии на скорость фотоокисления I ввода в систему любого из изучаемых бензопроизводных антрацена в пределах значений $M / M_{0}$ вплоть до 2.

При соокислении I с II или IV в бинарной смеси скорость его превращения закономерно снижается, причем ингибирующее действие II оказывается более значительным. Напротив, наличие III в бинарной смеси столь же закономерно ускоряет его деградацию. В тройной системе I-II-III (см. данные для опытов 10 и 11 в табл. 2) влияние II и III на скорость превращения основного канцерогенного ПАУ суммируется (см. рисунок).

Следует напомнить, что при раздельном фотоокислении наибольшей реакционной способностью обладает III (скорость его превращения примерно в 70 раз больше скорости для II). Реакционная способность изученных соединений возрастает в ряду: IV $<$ II $<$ I $<$ III $\left[{ }^{4}\right]$. В соответствии со сказанным, в фотохимической системе, так же как и в некоторых биологических системах [6], бенз(а) антрацен и дибенз (a, с) антрацен являются выраженными ингибиторами окисления бенз(а)пирена. Влияние же бенз (b) антрацена линейной структуры (или тетрацена), обладающего значительно повышенной реакционной способностью в сравнении с остальными ПАУ, сводится к значительному ускорению деградации бенз (а) пирена.

ЛИТЕР А Т У Р А

1. Па альме Л. П., Ки исо У. Э., К ару Т., Гу бе ргр.иц М. Я., Вопр. онкологии, № 10,56 (1975).

2. Паальме Л., Г уб ер гриц М., Изв. АН ЭССР. Хим. Геол., 25, № 4 (1976).

3. Па альме Л. П., Губергриц М. Я.,, В сб.: Теория и практика жидкофазного окисления. М., 1974 , с. 120.

4. Па альме Л., Туулмет с А., Кирсо У., Гу бергриц М., Реакц. способн. орг. соед., 11, вып. 2 (40), 313 (1974).

5. П а альм е Л.. Г убе р гр иц М., Изв. АН ЭССР. Хим. Геол., 22, 317 (1973).

6. Kunte, H., Z. Krebsforsh., 72, 57 (1969).

Ннститут химии

Академии наук Эстонской ССР
Поступила в редакцию 11/VII 1976 